\title{
STUDY OF THE RELATIONSHIP BETWEEN Androctonus crassicauda (OLIVIER, 1807; SCORPIONES, BUTHIDAE) VENOM TOXICITY AND TELSON SIZE, WEIGHT AND STORING CONDITION
}

\author{
OZKAN O. (1), ADIGUZEL S. (1), YAKISTIRAN S. (1), FILAZI A. (2)
}

(1) Refik Saydam Hygiene Center, Ankara, Turkey; (2) Department of Toxicology and Pharmacology, Faculty of Veterinary Medicine, Ankara University, Ankara, Turkey.

\begin{abstract}
Scorpions are included in the order Scorpiones; class Arachnida. Lethal scorpions are mostly of the Buthidae family. Among these, species belonging to Androctonus, Leiurus and Mesobuthus genera cause most scorpion envenomations in Turkey. This study was performed aiming the production of antivenom by using Androctonus crassicauda telsons. Venom toxicity is related to telson weight, size, and storing condition (open or closed). Telsons of $A$. crassicauda were collected in Southeastern Anatolia (especially in Harran town, Sanliurfa), Turkey. They were separated according to weight, size, and storing condition - open (a) and closed (b). Venom solution was prepared by maceration of telsons. Swiss albino mice were used to determine the lethal dose $50 \%\left(\mathrm{LD}_{50}\right)$, which was as follows: Group 1a - 2.31mg; Group 1b - 2.66mg; Group 2a - 2.32mg; Group 2b $2.66 \mathrm{mg}$; Group 3a-6.66mg; Group 3b-6.88mg. Among the groups of telsons, the first and the second groups showed different characteristics. However, there were no differences between their toxicity. In the third group, a fourfold amount of telsons was used for toxicity. In other words, telsons weighting from 19.99 to $20 \mathrm{mg}$ (first group) and from 29.99 to $30 \mathrm{mg}$ (second group) presented similar $\mathrm{LD}_{50}$ values, and telsons weighting from 10 to $19.99 \mathrm{mg}$ (third group) showed a fourfold higher $\mathrm{LD}_{50}$ value. This difference was caused by the maturity of scorpions and venom toxicity was related to their size. The first and second groups were considered to be mature and the third group, not adult. Therefore, we can conclude that obtaining open telsons due to environmental factors was not effective for venom toxicity.
\end{abstract}

KEY WORDS: scorpion, Androctonus crassicauda (Oliver, 1807), telson size and weight, $\mathrm{LD}_{50}$, acute toxicity.

\section{CORRESPONDENCE TO:}

OZCAN OZKAN, Poison Research Center, Refik Saydam Hygiene Center, Ankara, Turkey. Phone: 0090312 4337001. Fax: 00903124337000.

Email: ozcanozkan62@hotmail.com. 
O. Ozkan et al. STUDY OF THE RELATIONSHIP BETWEEN Androctonus crassicauda (OLIVIER, 1807; SCORPIONES, BUTHIDAE) VENOM TOXICITY AND TELSON SIZE, WEIGHT AND STORING CONDITION. J. Venom. Anim. Toxins incl. Trop. Dis., 2006, 12, 2, p.298

\section{INTRODUCTION}

Scorpion sting is the most important arachnidan envenomation that causes adult morbidity and child mortality. It remains a real health problem in many countries from tropical and subtropical regions $(4,13,14,15,17,20,27)$.

Scorpion venom contains small neurotoxin polypeptides consisting of low-molecularweight simple proteins with lethal and paralytic effects $(1,3,15,28)$. Several studies on scorpion stings emphasized that clinical pictures ranged from local to severe autonomic and central nervous system symptoms and also death due to cardio and respiratory failure, especially in children $(5,7,10,11,12,17,18,21,22)$. Lethal scorpions are mostly of the Buthidae family $(16,18,27)$.

In Turkey, scorpion envenomations are mostly caused by the genera Androctonus, Leiurus and Mesobuthus $(18,19)$. In the same country, A. crassicauda venom, obtained by maceration of telsons, is utilized as antigen for antivenom. This antigen has also been used against other scorpion species $(23,24)$. Therefore, the aim of this study was to verify the relationship between $A$. crassicauda venom toxicity and its telson size, weight, and storing condition.

\section{MATERIALS AND METHODS}

\section{Telsons}

Androctonus crassicauda scorpions were collected in Southeastern Anatolia (especially in Harran town, Sanliurfa), Turkey. Telsons were separated according to their weight, size and storing condition (Figures 1, 2 and 3).

All telsons were weighted by using an electronic scale with sensitivity of $0.001 \mathrm{mg}$. Telsons were randomly divided into three base groups. They were measured by using metal capillars, sensitivity of $0.1 \mathrm{~mm}$, considering the morphometric parameters (length, width, heigth) decribed by Vachon $(25,26)$.

\section{Mice}

Four hundred and sixty-four healthy female Swiss albino mice, weighing $23 \pm 1 \mathrm{~g}$, and 8 weeks old, were used to determine $L_{50}$. Throughout the experiment, the animals were kept in a laboratory under room temperature of $22 \pm 2^{\circ} \mathrm{C}$ and $60 \pm 10 \%$ humidity. They were fed with commercial mouse pellets ad libitum. 
O. Ozkan et al. STUDY OF THE RELATIONSHIP BETWEEN Androctonus crassicauda (OLIVIER, 1807; SCORPIONES, BUTHIDAE) VENOM TOXICITY AND TELSON SIZE, WEIGHT AND STORING CONDITION. J. Venom. Anim. Toxins incl. Trop. Dis., 2006, 12, 2, p.299

\section{Preparation of Venom Solution}

Venom solution was prepared by maceration $(2,14)$ of telsons from the six groups used (base groups $-1^{\text {st }}, 2^{\text {nd }}$, and $3^{\text {rd }}$ groups - and their subgroups - open and closed telsons). Telsons were ground to a fine powder, which was dissolved in physiologic saline solution (PSS; chloride solution of $0.9 \%$ ).

\section{Lethal dose $50 \%\left(L_{50}\right)$ assay}

A different concentration of venom solution was prepared for each group of mice. Then, $0.5 \mathrm{ml}$ was subcutaneously injected into each mouse. Control groups were treated with $0.5 \mathrm{ml}$ PSS, subcutaneously. After treatment, animals were monitored for 48 hours, and the number of dead animals was recorded at the end of the experiment. The dose that killed $50 \%$ of animals $\left(L D_{50}\right)$ was calculated by probit analysis (9).

\section{Statistical analysis}

Results were statistically evaluated by using probit analysis, Pearson's chi-square test and the probability value $p$. Telson size values were presented as mean \pm standart derivation (SD). Differences were considered significant when $p<0.005$.

\section{RESULTS}

\section{Telsons}

We used 524 telsons from $A$. crassicauda scorpions. According to weight, telsons were divided into three groups in the following manner: First group, 30-39.99mg; second group, 20-29.99mg; and third group, 10-19.99mg (Tables 2A, 2B and 2C). Within these base groups, there were two subgroups according to the storing condition: open (a) and closed (b). The mean weights of telsons were: First group, 33.46mg; second group, 24.64mg; third group, 16.47mg, as shown in Table 1.

Telsons were randomly divided into base groups and the measurements of their morphometric parameters (length, width, heigth) were also shown in Table 1.

A stock venom solution at a concentration of $20 \mathrm{mg} / \mathrm{ml}$ was prepared through maceration of telsons. 
O. Ozkan et al. STUDY OF THE RELATIONSHIP BETWEEN Androctonus crassicauda (OLIVIER, 1807; SCORPIONES, BUTHIDAE) VENOM TOXICITY AND TELSON SIZE, WEIGHT AND STORING CONDITION. J. Venom. Anim. Toxins incl. Trop. Dis., 2006, 12, 2, p.300

\section{Animals}

In the determination of $L D_{50}$ values, Group 1 consisted of 64 mice in $\mathrm{G} 1_{\mathrm{a}}, 72$ mice in $\mathrm{G} 1_{\mathrm{b}}$, and 8 mice in the control group [G $1^{1}$ ]; Group 2 was comprised of 72 mice in $\mathrm{G} 2_{\mathrm{a}}, 72$ mice in $\mathrm{G} 2_{\mathrm{b}}$, and 8 mice in the control group [G2 ${ }^{1}$ ]; Group 3 presented 80 mice in $\mathrm{G}_{\mathrm{a}}, 80$ mice in $\mathrm{G} 3_{\mathrm{b}}$, and 8 mice in the control group [G3 ${ }^{1}$ ] (Tables $2 \mathrm{~A}, 2 \mathrm{~B}$ and $2 C$ ). The $L_{50}$ was found (95\% confidence limit - CL) for each group and is presented in Table 3.

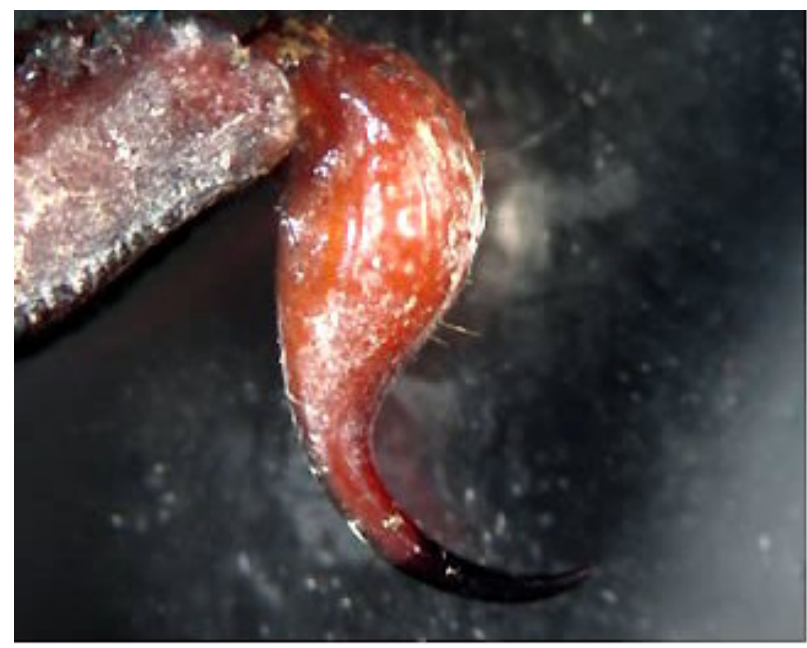

Figure 1: Telson of Androctonus crassicauda (by Ozkan O. et al. J. Venom. Anim. Toxins incl. Trop. Dis., 2006, 12, 297-309).

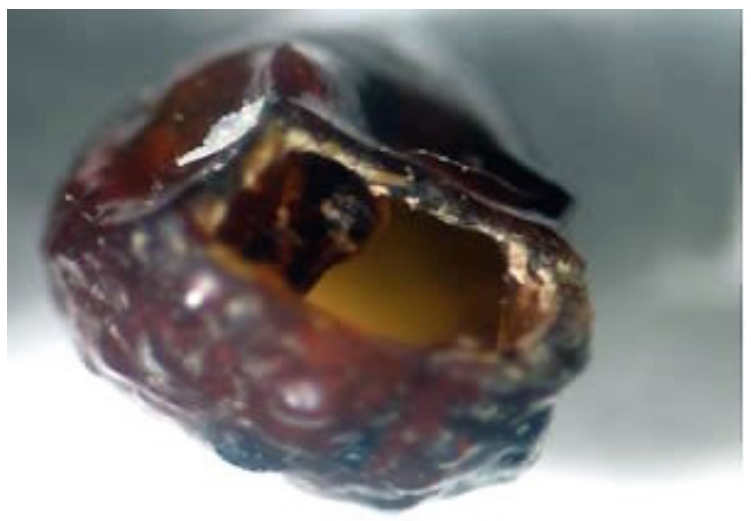

Figure 2: The view of an open telson (by Ozkan O. et al. J. Venom. Anim. Toxins incl. Trop. Dis., 2006, 12, 297-309). 
O. Ozkan et al. STUDY OF THE RELATIONSHIP BETWEEN Androctonus crassicauda (OLIVIER, 1807; SCORPIONES, BUTHIDAE) VENOM TOXICITY AND TELSON SIZE, WEIGHT AND STORING CONDITION. J. Venom. Anim. Toxins incl. Trop. Dis., 2006, 12, 2, p.301

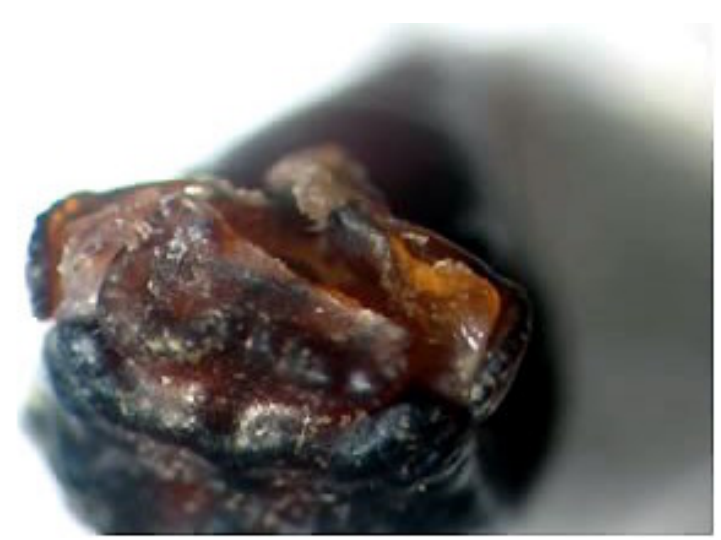

Figure 3: The view of a closed telson (by Ozkan O. et al. J. Venom. Anim. Toxins incl. Trop. Dis., 2006, 12, 297-309).

Table 1: Groups of telsons and their morphometric characteristics. There were not statistically significant differences according to weight and morphometric parameters $(p>0.005)$.

\begin{tabular}{c|c|c|c|c|c|c}
\hline Group & Telsons & Total & Mean & \multicolumn{2}{|c}{ Morphometric parameters (mm) } \\
\cline { 5 - 7 } & $(\mathbf{n = 5 2 4 )}$ & weight & weight & Width & Length & Height \\
\cline { 5 - 7 } & & $(\mathbf{g})$ & $\mathbf{( m g )}$ & Mean \pm SD & Mean \pm SD & Mean \pm SD \\
\hline 1st & 68 & 2.27 & 33.46 & $0.445 \pm 0.021^{*}$ & $0.104 \pm 0.039^{*}$ & $0.352 \pm 0.006^{*}$ \\
\hline 2nd & 241 & 5.93 & 24.64 & $0.397 \pm 0.020^{*}$ & $0.960 \pm 0.056^{*}$ & $0.308 \pm 0.013^{*}$ \\
\hline 3rd & 215 & 3.54 & 16.47 & $0.325 \pm 0.022^{* *}$ & $0.857 \pm 0.032^{* *}$ & $0.290 \pm 0.016^{\star *}$ \\
\hline
\end{tabular}

${ }^{*}$ Mature scorpions

** Not adult scorpions 
O. Ozkan et al. STUDY OF THE RELATIONSHIP BETWEEN Androctonus crassicauda (OLIVIER, 1807; SCORPIONES, BUTHIDAE) VENOM TOXICITY AND TELSON SIZE, WEIGHT AND STORING CONDITION. J. Venom. Anim. Toxins incl. Trop. Dis., 2006, 12, 2, p.302

Table 2A: Number of animals in each subgroup, amount of venom used, and number of dead animals in Group 1 (injected with venom solution from telsons weighting from 30 to $39.9 \mathrm{mg}$ ).

\begin{tabular}{|c|c|c|c|c|}
\hline Groups & Subgroups & $\begin{array}{l}\text { Number of } \\
\text { animals }\end{array}$ & $\begin{array}{c}\text { Amount of venom } \\
\text { (mg/mouse) }\end{array}$ & $\begin{array}{c}\text { Number of dead } \\
\text { animals }\end{array}$ \\
\hline $\mathrm{G} 1^{1}$ & - & 8 & - & 0 \\
\hline \multirow{9}{*}{$\mathrm{G} 1_{\mathrm{a}}$} & $\mathrm{G} 1_{\mathrm{a}-1}$ & 8 & 1.50 & 0 \\
\hline & $\mathrm{G} 1_{\mathrm{a}-2}$ & 8 & 1.75 & 1 \\
\hline & $\mathrm{G} 1_{\mathrm{a}-3}$ & 8 & 2.0 & 3 \\
\hline & $\mathrm{G} 1_{\mathrm{a}-4}$ & 8 & 2.25 & 5 \\
\hline & $\mathrm{G} 1_{\mathrm{a}-5}$ & 8 & 2.50 & 6 \\
\hline & $\mathrm{G} 1_{\mathrm{a}-6}$ & 8 & 2.75 & 6 \\
\hline & $\mathrm{G} 1_{\mathrm{a}-7}$ & 8 & 3.0 & 6 \\
\hline & $\mathrm{G} 1_{\mathrm{a}-8}$ & 8 & 3.25 & 7 \\
\hline & $\mathrm{G} 1_{\mathrm{a}-9}$ & 8 & 3.50 & 8 \\
\hline \multirow{9}{*}{$\mathrm{G} 1_{b}$} & $\mathrm{G} 1_{\mathrm{b}-1}$ & 8 & 1.50 & 0 \\
\hline & $\mathrm{G} 1_{\mathrm{b}-2}$ & 8 & 1.75 & 0 \\
\hline & $\mathrm{G} 1_{\mathrm{b}-3}$ & 8 & 2.0 & 1 \\
\hline & $\mathrm{G} 1_{\mathrm{b}-4}$ & 8 & 2.25 & 2 \\
\hline & $\mathrm{G} 1_{\mathrm{b}-5}$ & 8 & 2.50 & 3 \\
\hline & $\mathrm{G} 1_{\mathrm{b}-6}$ & 8 & 2.75 & 4 \\
\hline & $\mathrm{G} 1_{\mathrm{b}-7}$ & 8 & 3.0 & 6 \\
\hline & $\mathrm{G} 1_{\mathrm{b}-8}$ & 8 & 3.25 & 7 \\
\hline & $\mathrm{G} 1_{b-9}$ & 8 & 3.50 & 8 \\
\hline
\end{tabular}

G1': Control group

G1 a: Groups injected with venom solution from closed telsons

$G 1_{b}$ : Groups injected with venom solution from open telsons 
O. Ozkan et al. STUDY OF THE RELATIONSHIP BETWEEN Androctonus crassicauda (OLIVIER, 1807; SCORPIONES, BUTHIDAE) VENOM TOXICITY AND TELSON SIZE, WEIGHT AND STORING CONDITION. J. Venom. Anim. Toxins incl. Trop. Dis., 2006, 12, 2, p.303

Table 2B: Number of animals in each subgroup, amount of venom used, and number of dead animals in Group 2 (injected with venom solution from telsons weighting from 20 to $29.9 \mathrm{mg}$ ).

\begin{tabular}{|c|c|c|c|c|}
\hline Groups & Subgroups & $\begin{array}{c}\text { Number of } \\
\text { animals }\end{array}$ & $\begin{array}{c}\text { Amount of venom } \\
\text { (mg/mouse) }\end{array}$ & $\begin{array}{c}\text { Number of dead } \\
\text { animals }\end{array}$ \\
\hline$G 2^{1}$ & - & 8 & & 0 \\
\hline \multirow{9}{*}{$\mathrm{G} 2_{\mathrm{a}}$} & $G 2_{a-1}$ & 8 & 1.50 & 0 \\
\hline & $G 2_{a-2}$ & 8 & 1.75 & 0 \\
\hline & $G 2_{a-3}$ & 8 & 2.0 & 4 \\
\hline & G2a-4 & 8 & 2.25 & 5 \\
\hline & $G 2_{a-5}$ & 8 & 2.50 & 6 \\
\hline & $G 2_{a-6}$ & 8 & 2.75 & 6 \\
\hline & $G 2_{a-7}$ & 8 & 3.0 & 7 \\
\hline & $G 2_{a-8}$ & 8 & 3.25 & 7 \\
\hline & $G 2_{a-9}$ & 8 & 3.50 & 8 \\
\hline \multirow{9}{*}{$G 2_{b}$} & $G 2_{b-1}$ & 8 & 1.50 & 0 \\
\hline & $G 2_{b-2}$ & 8 & 1.75 & 1 \\
\hline & $G 2_{b-3}$ & 8 & 2.0 & 3 \\
\hline & $G 2_{b-4}$ & 8 & 2.25 & 5 \\
\hline & $G 2_{b-5}$ & 8 & 2.50 & 6 \\
\hline & $G 2_{b-6}$ & 8 & 2.75 & 6 \\
\hline & $G 2_{b-7}$ & 8 & 3.0 & 7 \\
\hline & $G 2_{b-8}$ & 8 & 3.25 & 7 \\
\hline & G2b-9 & 8 & 3.50 & 8 \\
\hline
\end{tabular}

G2 ${ }^{1}$ : Control group

G2a: Groups injected with venom solution from closed telsons

$G 2_{b}$ : Groups injected with venom solution from open telsons 
O. Ozkan et al. STUDY OF THE RELATIONSHIP BETWEEN Androctonus crassicauda (OLIVIER, 1807; SCORPIONES, BUTHIDAE) VENOM TOXICITY AND TELSON SIZE, WEIGHT AND STORING CONDITION. J. Venom. Anim. Toxins incl. Trop. Dis., 2006, 12, 2, p.304

Table 2C: Number of animals in each subgroup, amount of venom used, and number of dead animals in Group 3 (injected with venom solution from telsons weighting from 10 to $19.9 \mathrm{mg}$ ).

\begin{tabular}{|c|c|c|c|c|}
\hline Groups & Subgroups & $\begin{array}{c}\text { Number of } \\
\text { animals }\end{array}$ & $\begin{array}{c}\text { Amount of venom } \\
\text { (mg/mouse) }\end{array}$ & $\begin{array}{c}\text { Number of dead } \\
\text { animals }\end{array}$ \\
\hline $\mathrm{G}^{1}$ & - & 8 & & 0 \\
\hline \multirow{10}{*}{$\mathrm{G}_{\mathrm{a}}$} & G3a-1 & 8 & 5.75 & 0 \\
\hline & $\mathrm{G3}_{\mathrm{a}-2}$ & 8 & 6.0 & 1 \\
\hline & $\mathrm{G3}_{\mathrm{a}-3}$ & 8 & 6.25 & 2 \\
\hline & $\mathrm{G3}_{\mathrm{a}-4}$ & 8 & 6.50 & 5 \\
\hline & $\mathrm{G3}_{\mathrm{a}-5}$ & 8 & 6.75 & 5 \\
\hline & $\mathrm{G3}_{\mathrm{a}-6}$ & 8 & 7.0 & 6 \\
\hline & $\mathrm{G3}_{\mathrm{a}-7}$ & 8 & 7.25 & 6 \\
\hline & $\mathrm{G}_{\mathrm{a}-8}$ & 8 & 7.50 & 7 \\
\hline & $\mathrm{G}_{\mathrm{a}-9}$ & 8 & 7.75 & 7 \\
\hline & $\mathrm{G}_{\mathrm{a}-10}$ & 8 & 8.0 & 8 \\
\hline \multirow{10}{*}{$\mathrm{G} 3_{\mathrm{b}}$} & $\mathrm{G}_{\mathrm{b}-1}$ & 8 & 5.75 & 0 \\
\hline & $G 3_{b-2}$ & 8 & 6.0 & 0 \\
\hline & $\mathrm{G}_{\mathrm{b}-3}$ & 8 & 6.25 & 1 \\
\hline & $\mathrm{G3}_{\mathrm{b}-4}$ & 8 & 6.50 & 4 \\
\hline & $\mathrm{G3}_{\mathrm{b}-5}$ & 8 & 6.75 & 4 \\
\hline & $\mathrm{G3}_{\mathrm{b}-6}$ & 8 & 7.0 & 5 \\
\hline & $\mathrm{G3}_{\mathrm{b}-7}$ & 8 & 7.25 & 5 \\
\hline & G3b-8 & 8 & 7.50 & 6 \\
\hline & $\mathrm{G}_{\mathrm{b}-9}$ & 8 & 7.75 & 7 \\
\hline & $\mathrm{G}_{b-10}$ & 8 & 8.0 & 8 \\
\hline
\end{tabular}

$\mathrm{G}^{1}$ : Control group

G3 : Groups injected with venom solution from closed telsons

$\mathrm{G}_{\mathrm{b}}$ : Groups injected with venom solution from open telsons 
O. Ozkan et al. STUDY OF THE RELATIONSHIP BETWEEN Androctonus crassicauda (OLIVIER, 1807; SCORPIONES, BUTHIDAE) VENOM TOXICITY AND TELSON SIZE, WEIGHT AND STORING CONDITION. J. Venom. Anim. Toxins incl. Trop. Dis., 2006, 12, 2, p.305

Table 3: Lethal dose $50 \%\left(\mathrm{LD}_{50}\right)$ and confidence limit determined for each group of mice. $L D_{50}$ were not significantly different between groups $(p>0.005)$.

\begin{tabular}{c|c|c}
\hline Groups & $\mathbf{L D}_{\mathbf{5 0}}\left(\mathbf{m g}^{*}\right)$ & 95\% Confidence Limit \\
\hline$G 1_{\mathrm{a}}$ & 2.31 & $2.05-2.53$ \\
\hline $\mathrm{G} 1_{\mathrm{b}}$ & 2.66 & $2.47-2.86$ \\
\hline $\mathrm{G} 2_{\mathrm{a}}$ & 2.32 & $2.11-2.52$ \\
\hline $\mathrm{G} 2_{\mathrm{b}}$ & 2.66 & $2.46-2.87$ \\
\hline $\mathrm{G} 3_{\mathrm{a}}$ & 6.66 & $6.42-6.88$ \\
\hline $\mathrm{G} 3_{\mathrm{b}}$ & 6.88 & $6.66-7.11$ \\
\hline
\end{tabular}

${ }^{*}$ Dry telsons

G1: Mice injected with venom solution from closed telsons weighting from 30 to $39.9 \mathrm{mg}$

$G 1_{b}$ : Mice injected with venom solution from open telsons weighting from 30 to $39.9 \mathrm{mg}$

G2: Mice injected with venom solution from closed telsons weighting from 20 to $29.9 \mathrm{mg}$

G2: : Mice injected with venom solution from open telsons weighting from 20 to $29.9 \mathrm{mg}$ G3: Mice injected with venom solution from closed telsons weighting from 10 to $19.9 \mathrm{mg}$ $\mathrm{G3}_{\mathrm{b}}$ : Mice injected with venom solution from open telsons weighting from 10 to $19.9 \mathrm{mg}$

\section{DISCUSSION}

The aim of this study was to determine the structure of $A$. crassicauda telsons, the $\mathrm{LD}_{50}$ of its venom, and the relationship between its telson weight, size and storing condition.

To obtain venom, we used maceration, manual techniques, and electrical stimulation (18). Maceration is one of the oldest and simplest methods based on the principle of keeping telsons of dead scorpions in physiologic saline solution $(1,18,23,24)$.

We prepared three different venom solutions containing $20 \mathrm{mg}$ of grounded telson $/ \mathrm{ml}$. These solutions were subcutaneously injected into mice when the average of telsons used was evaluated as one telson; mean $\operatorname{LD}_{50}$ was considered as $7 \%$ of the first group, $9.4 \%$ of the second group, and $40.4 \%$ of the third group. Although average $\mathrm{LD}_{50}$ values of the first and second groups were different, there were no significant differences between their toxicity; in the third group, it was observed that an amount of venom fourfold higher, compared with the other groups, was used because it presented lower toxicity, which was probably due to the fact that the scorpions were not mature yet. Also, toxicity changed because scorpions may have used some of 
O. Ozkan et al. STUDY OF THE RELATIONSHIP BETWEEN Androctonus crassicauda (OLIVIER, 1807; SCORPIONES, BUTHIDAE) VENOM TOXICITY AND TELSON SIZE, WEIGHT AND STORING CONDITION. J. Venom. Anim. Toxins incl. Trop. Dis., 2006, 12, 2, p.306

their venom for defense against being killed or caught or because they did not receive enough food during the experiment. In this study, similar results were seen in the first and second groups of telsons (20-40mg). Differently, Balozet declared the relationship between empty telson and full telson was 1:4 in order to kill mice (1). Although Balozet mentioned that factors such as transportation, drying method, storage conditions and usage period adopted could affect measurements (1), in this study, there were no differences between $L_{50}$ of telsons (open/closed), which became open due to environmental conditions.

In addition to Turkey, $A$. crassicauda has high prevalence in Azerbaijan, Iran, Iraq, Syria, Jordan, and Saudi Arabia (12, 18, 21, 27); and venom toxicity also changes according to regions and scorpion species (2). Total length of mature $A$. crassicauda varies from 90 to $100 \mathrm{~mm}(6,20)$. Measurements of telsons from the first and second groups (considered mature scorpions), and from the third group (considered not adult scorpions) are shown in Table 1.

According to lethality tests, different $L D_{50}$ values were found for the same species. Ismail et al. found that $\mathrm{LD}_{50}$ of $A$. crassicauda venom was $0.64 \mathrm{mg} / \mathrm{kg}$, whereas venom obtained from Latoxan laboratory had an $L_{50}$ of $0.87 \mathrm{mg} / \mathrm{kg}$ (12). Altinkurt and Altan (1) reported that $L D_{50}$ of venom of $A$. crassicauda from Sanliurfa region was $11.5 \mathrm{mg} / \mathrm{kg}$. Therefore, envenomation due to scorpion stings as well as local or systemic clinical effects could be related to the scorpion species, its feeding state, the telson structure, the amount of venom injected, the number of stings, the patient's sensitivity, age and weight, and the climate of the region $(1,7,8,21)$.

In this study, the average amount of venom obtained by maceration and subcutaneously injected into mice was $20 \mathrm{mg} / \mathrm{ml}$. The quantity that would kill a mouse (weighing approximately $23 \mathrm{~g}$ ) was calculated as $2.31 \mathrm{mg}$ [closed telsons] and $2.66 \mathrm{mg}$ [open telsons] (Table 3). Since a telson is about $20 \pm 1 \mathrm{mg}, 7 \%-8 \%$ of it corresponds to the $L_{50}$ of a mouse. This conclusion was similar to that of Ozkan and Filazi (18), who used the same species of scorpions. They stated that $3.6 \mathrm{mg}$ of grounded dry telson corresponds to the $\mathrm{LD}_{50}$ of a mouse (18). In our study, there were no differences between the subgroups and the base groups but the first and second groups of telsons were more toxic than the third group. However, the weight and size of telsons were not statistically significant $(p>0.005)$ and did not correlate with 
O. Ozkan et al. STUDY OF THE RELATIONSHIP BETWEEN Androctonus crassicauda (OLIVIER, 1807; SCORPIONES, BUTHIDAE) VENOM TOXICITY AND TELSON SIZE, WEIGHT AND STORING CONDITION. J. Venom. Anim. Toxins incl. Trop. Dis., 2006, 12, 2, p.307

toxicity. Tulga, using the same species of scorpions but different methodology, showed that $3.3 \%-5 \%$ of a telson corresponded to the $\operatorname{LD}_{50}$ of a mouse $(23,24)$.

Another study reported that differences between toxicities of scorpion venoms could be explained by the collection of scorpions as well as changes in their physiologic statuses and feeding patterns. Furthermore, during capturing and killing, the scorpions could have used some quantity of their venom to protect themselves. In addition, as already stated, factors such as transporting conditions, drying method, storage, and period of use of telsons could have influenced these differences (18).

Consequently, in our study, telsons weighting form 19.99 to $20 \mathrm{mg}$ (first group) and from 29.99 to $30 \mathrm{mg}$ (second group) had LD $_{50}$ values similar to each other and telsons weighting from 10 to $19.99 \mathrm{mg}$ (third group) presented fourfold higher values. This difference was caused by the maturity of scorpions (biological status) and venom toxicity was related to their size. Therefore, it was seen that obtaining open telsons due to environmental factors was not effective for venom toxicity.

\section{ACKNOWNLEDGMENTS}

We wish to thank Karina Chamma for her valuable comments on the manuscript.

\section{REFERENCES}

1 ALTINKURT O., ALTAN M. Pharmocological effects of the scorpion (Androctonus crassicauda) venom from Urfa environment on laboratory animals and the antagonistic effects of streptomycin to most of these effects. J. Fac. Pharm. Ankara. 1980, 10, 41-6.

2 AMARAL CF., REZENDE NA. Treatment of scorpion envenoming should include both a potent specific antivenom and support of vital functions. Toxicon, 2000, $38,1005-7$.

3 AY I., TUNCER M., ONUR R. Effects of Androctonus crassicauda scorpion venom on endothelium-dependent and independent vascular responses of rabbit aorta. Gen. Pharmacol., 1996, 27, 519-23.

4 BALOZET L. Scorpionism in the Old World. BÜCHERL W., BUCKLEY E. Eds. Venomous animals and their venoms. Venomous intervertebrates. New York: Academic Express, 1971: 349-71.

5 BLUM A., JAWABREH S., GUMANOVSKY M., SOBOH S. Scorpion envenomation and myocardial damage. Isr. Med. Assoc. J., 2000, 2, 318-9. 
O. Ozkan et al. STUDY OF THE RELATIONSHIP BETWEEN Androctonus crassicauda (OLIVIER, 1807; SCORPIONES, BUTHIDAE) VENOM TOXICITY AND TELSON SIZE, WEIGHT AND STORING CONDITION. J. Venom. Anim. Toxins incl. Trop. Dis., 2006, 12, 2, p.308

6 DEMIRSOY A. Invertabrate (out of Insecta), Vol II/Part I, METEKSAN Published, (2th.ed.). 1998, 734-9.

7 DE ROODT AR., GARCIA SI., SALOMON OD., SEGRE L., DOLAB SA., FUNES RF., DE TITTO EH. Epidemiological and clinical aspects of scorpionism by Tityus trivittatus in Argentina. Toxicon, 2003, 41, 971-7.

8 DITTRICH K., POWER AP., SMITH NA., Scorpion sting syndrome: a ten year experience. Ann. Saudi Med., 1995, 15, 148-55.

9 FINNEY DJ. Probit analysis. 3.ed. London: Cambridge University Press, 1971. 333p.

10 HISHAM MAHABA MA. Scorpion sting syndrome: epidemiology, clinical presentation and management of 2240 cases. East. Mediterr. Health J., 1997, 3, 82-9.

11 ISBISTER GK., GRAUDINS A., WHITE J., WARRELL D. Antivenom treatment in Arachnidism. J. Toxicol. Clin. Toxicol., 2003, 41, 291-300.

12 ISMAIL M., ABD-ELSALAM MA., AL-AHAIDIB MS. Androctonus crassicauda (Olivier), a dangerous and unduly neglected scorpion - I. Pharmacological and clinical studies. Toxicon, 1994, 32, 1599-618.

13 KRIFI MN., MARRAKCHI N., EL AYEB M., DELLAGI K. Effect of some variables on the in vivo determination of scorpion and viper venom toxicities. Biologicals, 1998, 26, 277-88.

14 LOURENÇO WR., CUELLAR O. Scorpions, scorpionism, life history strategies and parthenogenesis. J. Venom. Anim. Toxins, 1995, 1, 51-62.

15 MAHADEVAN S. Scorpion sting. Indian Pediatr., 2000, 37, 504-14.

16 MULLEN G., STOCKWELL SA. Scorpions (Scorpiones) In: MULLEN G., DURDEN L. Eds. Medical and veterinary entomology. Amsterdam: Academic Press, 2002: 411-23.

17 OSNAYA-ROMERO N., DE JESUS MEDINA-HERNANDEZ T., FLORESHERNANDEZ SS., LEON-ROJAS G. Clinical symptoms observed in children envenomated by scorpion stings, at the Children's Hospital from the state of Morelos, Mexico. Toxicon, 2001, 39, 781-5.

18 OZKAN O., FILAZI A. The determination of acute lethal dose-50 (LD 50$)$ levels of venom in mice, obtained by different methods from scorpions Androctonus crassicauda (Oliver 1807). Acta Parasitol. Turcica, 2004, 28, 50-3. 
O. Ozkan et al. STUDY OF THE RELATIONSHIP BETWEEN Androctonus crassicauda (OLIVIER, 1807; SCORPIONES, BUTHIDAE) VENOM TOXICITY AND TELSON SIZE, WEIGHT AND STORING CONDITION. J. Venom. Anim. Toxins incl. Trop. Dis., 2006, 12, 2, p.309

19 OZKAN O., KARAER Z. The scorpions in Turkey. Turk. Bull. Hyg. Exp. Biol., 2003, $60,55-62$.

20 OZKAN O., KARAER Z. Body structures of scorpions. Acta Parasitol. Turcica, 2004, 28, 54-8.

21 RADMANESH M. Androctonus crassicauda sting and its clinical study in Iran. $J$. Trop. Med. Hyg., 1990, 93, 323-6.

22 SEDDIK SS., WANAS S., SHEHATA A., FAWAZ S., HELMY MH. Development of an improved method for production of antiscorpion $F\left(a b^{\prime}\right)_{2}$ fragment of $\lg G$ with high yield and potency. J. Nat. Toxins, 2002, 11, 123-32.

23 TULGA T. Cross-reactions between anti-scorpion (Buthus quinquestriatus) and anti-scorpion (Prionurus crassicauda) sera. Turk. Bull. Hyg. Exp. Biol., 1960, 20, 191-03.

24 TULGA T. Scorpions found in Turkey and paraspecific action of an antivenin produced with the venom of the species Androctonus crassicauda. Turk. Bull. Hyg. Exp. Biol., 1964, 24, $146-155$.

$25 \mathrm{VACHON} \mathrm{M.} \mathrm{Études} \mathrm{sur} \mathrm{les} \mathrm{scorpions} \mathrm{(morphologie,} \mathrm{bionomie} \mathrm{et} \mathrm{repartition}$ mondiale). Inst. Pasteur d'Algérie, 1952a, 1-44.

26 VACHON M. Études sur les scorpions: caracteres servant a la classification. Inst. Pasteur d'Algérie, 1952b, 45-70.

27 VATANPOUR H. Effects of black scorpion Androctonus crassicauda venom on striated muscle preparation in vitro. Iranian J. Pharmaceutical Res., 2003, 2, 17-22.

28 ZLOTKIN E., MIRANDA F., ROCHAT H. Chemistry and pharmacology of Buthinae scorpion venoms. In: BETTINI S. Ed. Handbook of experimental pharmacology-arthropod venoms. Berlin: Spinger-Verlag, 1978: 317-69. 